\title{
A millennium-length reconstruction of Bear River stream flow, Utah
}

\author{
R.J. DeRose ${ }^{\mathrm{a}, *}$, M.F. Bekker ${ }^{\mathrm{b}}$, S.-Y. Wang ${ }^{\mathrm{c}}$, B.M. Buckley ${ }^{\mathrm{d}}$, R.K. Kjelgren ${ }^{\mathrm{c}}$, T. Bardsley ${ }^{\mathrm{e}}$, T.M. Rittenour ${ }^{\mathrm{f}}$, \\ E.B. Allen ${ }^{\mathrm{g}}$ \\ ${ }^{a}$ USDA, Forest Service, Forest Inventory and Analysis, Rocky Mountain Research Station, 507 25th Street, Ogden, UT 84401, United States \\ ${ }^{\mathrm{b}}$ Department of Geography, 690 SWKT, Brigham Young University, Provo, UT 84602, United States \\ c Plant, Soil, and Climate Department, 4820 Old Main Hill, Utah State University, Logan, UT 84322-4820, United States \\ ${ }^{\mathrm{d}}$ Tree Ring Lab, Room 108, Lamont-Doherty Earth Observatory, Columbia University, 61 Route 9W, Palisades, NY 10964, United States \\ e Western Water Assessment, 2242 West North Temple, Salt Lake City, UT 84116, United States \\ ${ }^{\mathrm{f}}$ Department of Geology, 4505 Old Main Hill, Utah State University, Logan, UT 84322-4505, United States \\ ${ }^{\mathrm{g}}$ United States Geological Survey, 4200 New Haven Road, Columbia, MO 65201, United States
}

\section{A R T I C L E I N F O}

\section{Article history:}

Available online 17 January 2015

\section{Keywords:}

Dendrohydrology

Drought

Medieval Warm Period

Mega-droughts

Pacific Ocean teleconnection

Water management

\begin{abstract}
S U M M A R Y
The Bear River contributes more water to the eastern Great Basin than any other river system. It is also the most significant source of water for the burgeoning Wasatch Front metropolitan area in northern Utah. Despite its importance for water resources for the region's agricultural, urban, and wildlife needs, our understanding of the variability of Bear River's stream flow derives entirely from the short instrumental record (1943-2010). Here we present a 1200-year calibrated and verified tree-ring reconstruction of stream flow for the Bear River that explains $67 \%$ of the variance of the instrumental record over the period from 1943 to 2010. Furthermore, we developed this reconstruction from a species that is not typically used for dendroclimatology, Utah juniper (Juniperus osteosperma). We identify highly significant periodicity in our reconstruction at quasi-decadal ( $7-8$ year), multi-decadal (30 year), and centennial ( $>50$ years) scales. The latter half of the 20 th century was found to be the 2 nd wettest ( $~ 40$-year) period of the past 1200 years, while the first half of the 20th century marked the 4 th driest period. The most severe period of reduced stream flow occurred during the Medieval Warm Period (ca. mid-1200s CE) and persisted for $\sim 70$ years. Upper-level circulation anomalies suggest that atmospheric teleconnections originating in the western tropical Pacific are responsible for the delivery of precipitation to the Bear River watershed during the October-December (OND) season of the previous year. The Bear River flow was compared to recent reconstructions of the other tributaries to the Great Salt Lake (GSL) and the GSL level. Implications for water management could be drawn from the observation that the latter half of the 20th century was the 2 nd wettest in 1200 years, and that management for future water supply should take into account the stream flow variability over the past millennium.
\end{abstract}

Published by Elsevier B.V.

\section{Introduction}

The Bear River is located in the heart of the Intermountain U.S., and is one of the largest sources of underdeveloped surface water in three states, Idaho, Utah, and Wyoming (DWR, 2004). Originating in the western Uinta Mountains of Utah, the Bear River follows a tortuous path, meandering across the Utah-Wyoming border several times, before entering the same valley as Bear Lake, then looping back through southeastern Idaho before becoming the largest inflow to the Great Salt Lake. The Bear River is the single largest river in the eastern Great Basin, and demand for its water is high. It is used for rural, urban, and wildlife purposes (e.g., the

\footnotetext{
* Corresponding author. Tel.: +1 8016255795.

E-mail address: rjderose@fs.fed.us (R.J. DeRose).
}

Bear River Migratory Refuge). Moreover, flow is diverted through Bear Lake for water storage and to act as a buffer against regional drought (Endter-Wada et al., 2009; Welsh et al., 2013), and is the cornerstone for supplying water for the future growth of the Wasatch Front metropolitan region (DWR, 2004). However, water management on the Bear River is complex and despite its political, social, and geographic importance few studies have sought to quantify the variability of the Bear River's natural flow regime. In this paper we use tree rings to develop a 1200-year statistically calibrated and verified reconstruction of mean annual flow (MAF) from one of the Bear River headwater gages located near the Utah-Wyoming border. We then compare this reconstruction to other recent reconstructions of important tributaries to the Great Salt Lake, in order to provide the larger context of long-term hydrologic variability to this rapidly growing region. 
Regional tree-ring data provide a proven source of proxy information for stream flow that can be utilized for understanding long-term flow variability beyond the limits of historical records (Axelson et al., 2009; Strachan et al., 2011; Wise, 2010; Woodhouse et al., 2006). Although there is no direct physical relationship between ring width and stream flow, they both are reflective of common hydroclimatic variables such as precipitation, snowpack, and soil moisture, such that trees growing in the vicinity of arid region river systems often exhibit a strong relationship with both stream flow and precipitation (see, for example, Stockton and Jacoby, 1976). In particular, in the Four Corners region of the Colorado Plateau where the vast majority of precipitation is delivered in the cool season, roughly centered in the water year (WY, October-September), tree rings have been found to be excellent proxies of MAF.

Tree-ring reconstructions in the vicinity of Bear River have been lacking, but recent stream flow reconstructions of several water bodies on the Wasatch Front have improved our understanding of Bear River's hydroclimate: the Weber River (Bekker et al., 2014) - another tributary of the Great Salt Lake that originates near Bear River headwaters in the Western Uinta Mountains; the Logan River - the largest tributary to the Bear River (Allen et al., 2013); and Great Salt Lake level (DeRose et al., 2014). These studies have indicated incongruities in species-specific tree-ring responses to climate across the region. They also indicate that variation in reconstructed flow might represent differences (both spatially and temporally) in precipitation delivery to the Wasatch Front, primarily during the winter, that are important for water management. Decadal-scale climate oscillations originating in the tropical and North Pacific as recorded by the GSL elevation, for example, have been shown by various studies to dominate the hydrology of the Wasatch Front (Gillies et al., 2011; Wang et al., 2010, 2012).

For regional water managers tasked with planning for future demand, reconstructions of magnitude, intensity, and periodicity of stream flow variability at different temporal scales provide a solid basis to augment planning (Woodhouse and Lukas, 2006). Longer-term reconstructions spanning over a millennium can not only illuminate possible hydrologic extremes, but also reveal low-frequency variability that potentially affects the region with long-term, severe dry and wet periods (Cook et al., 2011). Finally, the annual resolution of tree-ring reconstructions provides a characterization of stream flow variability at a scale that may be more readily interpretable by water managers who can make comparisons with historical events (Woodhouse and Lukas, 2006).

Unlike other regions in western North America, e.g., in the FourCorners region of the Colorado Plateau, that have been explored using tree-ring data (Cook et al., 2007), the Bear River Watershed lacks an extensive network of tree-ring chronologies. Furthermore, three of the four most useful hydroclimate-sensitive species in the west, ponderosa pine (Pinus ponderosa), common pinyon (Pinus edulis), and singleleaf pinyon (Pinus monophylla) - are entirely lacking from the region. The fourth such species, interior Douglas-fir (Pseudotsuga menziesii), is present in the Bear River watershed, but has not been particularly useful. Older Douglas-fir individuals are rare due to extensive resource extraction by Mormon settlers since their arrival in the mid 1800s (Bekker and Heath, 2007), and the few extant old stands typically occur at higher elevation where their ring-width is less sensitive to precipitation (e.g. Hidalgo et al., 2001). This paucity of moisture-sensitive species for the Bear River watershed is a predicament we have resolved by focusing on species that are not commonly used for dendroclimatology, Rocky Mountain juniper (Juniperus scopulorum) (Allen et al., 2013), see also (Spond et al., 2014), and especially Utah juniper (Juniperus osteosperma). These species are usually found at sites characterized by limited available water-low elevations, southerly exposures, and limited soil development-and as a result often have a strong relationship between ring-width and hydroclimate, and yet they have long been considered too difficult to use for dendrochronology purportedly owing to false ring formation and extreme stem lobing (Fritts et al., 1965).

In this study we focus on living and dead Utah juniper trees that extend more than 1200 years into the past, and we use the data to reconstruct Bear River MAF from a near-natural headwater gage record located at the Utah-Wyoming border. We characterize wet and dry periods at annual- and decadal-scales as deviations from the mean condition with a particular focus on the period $\sim 800-1500$, as we provide the first long-term hydroclimatic information for the region that covers this time period. For the period of 1500 to the present we compare and contrast with other regional tree-ring based hydroclimate reconstructions that cover this same period from the Logan River (Allen et al., 2013), the Weber River (Bekker et al., 2014), and the Great Salt Lake (DeRose et al., 2014), but that used different species (Douglas-fir, common pinyon, Rocky mountain juniper, and limber pine (Pinus flexilis)). Finally, we examine circulation anomalies associated with precipitation in the region to elucidate climatic drivers of stream flow. Combining the new Bear River reconstruction with these other regional reconstructions and the potential climatological drivers results in a more comprehensive characterization of past hydroclimatology for northern Utah, and provides the fullest picture to-date of regional stream flow variability for a rapidly growing metropolitan region of the Intermountain West.

\section{Methods}

\subsection{Regional climate}

The climate of the greater Bear River region exhibits a stark contrast between cold and warm seasons. The vast majority of annual precipitation comes in the form of winter snowpack from storms that originate in the Pacific Ocean, while summers are typically and predictably dry (i.e., the summer monsoon system that brings rains to the US Southwest does not typically extend into northern Utah, Mock, 1996). Stream discharge in this region is strongly related to the quantity of snowpack, spring precipitation, antecedent soil moisture conditions, and temperature during the transition between the cool season and the growing season. Furthermore, northern Utah exhibits a strong 'seasonal drought' during the summer, characterized as sparse precipitation from July through September. Therefore, water-year characterization of stream discharge integrates the primary conditions thought to also influence tree-ring increment, winter snowpack and spring moisture. Influence by the North American Monsoon on the hydroclimate of this region is possible but rare (MacDonald and Tingstad, 2007; Mock, 1996). Any direct effect on plant growth this far north is likely due not to precipitation, but rather to increased humidity, which lowers vapor deficit and allows greater late growing season photosynthesis (Woodruff et al., 2010).

\subsection{Study area}

We collected core samples and cross-sections from Utah juniper living and dead trees, respectively, from the South Fork of Chalk Creek (SFC), a tributary to the Weber River that is directly adjacent to the Bear River watershed (Fig. 1, $2160 \mathrm{~m}$ asl). The site was selected from aerial imagery based on the presence of Utah juniper and was characterized by minimal soil development, little herbaceous cover, steep, south-facing slopes, and trees that were widely spaced. These are the basic conditions that are sought by dendroclimatologists because they minimize the availability of soil 


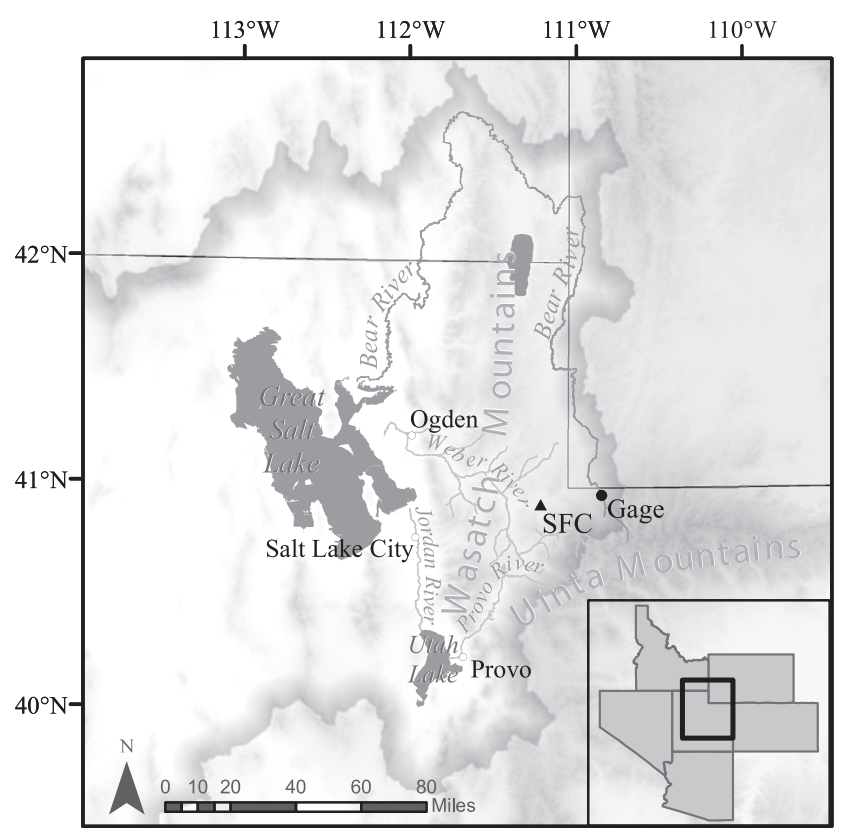

Fig. 1. Location of the Bear River, South Fork of Chalk Creek chronology (triangle) and USGS gage 10011500 (black circle).

moisture and thereby optimize ring-width sensitivity to climate (Fritts, 1976). SFC is also located in the rain shadow of the taller north-south trending Wasatch Mountain Range, which likely further reduces moisture availability for plant growth. It is also a remote location unlikely to have been impacted by settlementera resource extraction.

\subsection{Sample collection and preparation}

Sample collection at SFC focused on both living and dead-anddown Utah juniper trees. Where possible, two increment cores per tree were taken from living trees per conventional protocols (Stokes and Smiley, 1968), and cross-sections were removed with a chainsaw from both recent and older remnant wood. Cores and cross-sections were dried, mounted, and sanded with progressively finer grades of sandpaper following typical protocols (Stokes and Smiley, 1968), until individual cells were clearly visible under a binocular microscope. To ensure the temporal accuracy of the growth rings from this difficult species, crossdating was accomplished via the marker year method and skeleton plots, long the staple method of proper dendrochronology (Douglass, 1941; Speer, 2010; Stokes and Smiley, 1968; Yamaguchi, 1991). Ring widths were measured to $1-\mu \mathrm{m}$ resolution using a sliding stage attached to a Velmex and captured with program MeasureJ2X (http://www.voortech.com/projectj2x/). The accuracy of our crossdating was then assessed using the computer program COFECHA (Holmes, 1983).

\subsection{Chronology development}

The full SFC chronology included 73 series from 36 trees and incorporated a number of relatively young trees, which were necessary for determining the presence of the commonly absent rings 1934 and 1756. However, to avoid problems associated with the 'segment length curse' (Cook et al., 1995) we pared the full SFC chronology down to include only series that exceeded 250 years in length. The resultant chronology included 47 series from 20 trees (13 live, 7 dead). The oldest living Utah juniper had an inside date of 1426 (587 years old). Chronology statistics varied little after removing the younger tree-ring series (series intercorrelation was reduced slightly from 0.810 to 0.806 and the average mean sensitivity increased from 0.465 to 0.466 ). Mean series length increased from 316 to 405 years, allowing the examination of low-frequency variability in the time series (Cook et al., 1995).

Conservative detrending was performed for the tree-ring series to remove non-climatic (i.e. geometric) growth trends. We found that roughly half the series exhibited no trend (55\%), and were detrended using the mean, and for the other $45 \%$ we used a negative exponential model. We found this approach accentuated the year-to-year variability in ring-width increment without unnecessarily removing low-frequency climatic trends (Biondi and Qeadan, 2008a). Each series was standardized by dividing it by its fitted growth trend to produce a dimensionless ring-width index. Series were then averaged using a biweight mean and autoregressive modeling was applied. Variance stabilization was explored but had negligible effects on the resultant index and was therefore not applied. Basic COFECHA output and the Gini coefficient, an all-lag measure of ring-width variability (Biondi and Qeadan, 2008b), were used to characterize the resultant chronology. All analyses were conducted in the R computing environment (Bunn, 2008; R. Development Core Team, 2012).

\subsection{Stream flow data}

While there are many discharge gages on the Bear River, their records are characterized by incomplete data, heavily modified flows and diversions, and/or were not readily available due to issues of proprietary data ownership. The uppermost gage at the UT-WY border (USGS gage \#10011500) measured stream flow discharge immediately adjacent to the north slope of the Uinta Mountains (Fig. 1). Located just south of the UT-WY border this gage is located below the confluence of two major tributaries, Hayden Fork and Stillwater Fork, which we considered the Bear River headwater for this study. While this gage represents a relatively small portion of total Bear River flow (8\% based on an 1890-1977 estimation) it likely provides the best data available (Douglas et al., 1979). Elevation of the gage is $2428 \mathrm{~m}$ with a drainage area of around $445 \mathrm{~km}^{2}$. Furthermore, there are no diversions that affect this gage, and only a single, small storage reservoir, making it a desirable candidate for characterizing variability of the Bear River's natural flow. The gage record includes monthly and annual discharge from 1942 to the present. We aggregated monthly flow into water-year (October-September) mean annual flow (MAF) for the period 1944-2010, and converted this value into cubic meters per second (cms). The Bear River MAF did not exhibit any significant firstorder autocorrelation.

\subsection{Tree-ring response to climate}

The relationship between the SFC chronology, precipitation, temperature and stream flow were examined to assess the assumption of a physical linkage between precipitation and stream flow. Bootstrapped correlation function analysis was used initially to screen the predictor chronology for its relationship to monthly total precipitation and maximum temperature (Biondi and Waikul, 2004). Monthly total precipitation and monthly maximum temperatures associated with SFC (1895-2010) were extracted from the Parameter-elevation Regressions on an Independent Slopes Model (PRISM, http://www.prism.oregonstate.edu/) using an online interface (http://www.cefa.dri.edu/Westmap/Westmap_ home.php). The bootRes package (Zang and Biondi, 2013) was used in the R statistical environment (R. Development Core Team, 2012) to conduct the analysis. Maximum bootstrapped Pearson's correlation coefficients were found between the SFC standard chronology and monthly precipitation during the growing season (March 
through June, 0.21-0.46), and also for the previous cool season (October through January, 0.19-0.37). Moving correlation functions also indicated that the positive relationship between SFC and precipitation was consistent April through June of the growing season, and October through December of the cool season (data not shown). Significant correlations were found for monthly maximum temperature during growing season June $(-0.42)$. A moving correlation function (30-year window, overlapped by 5 years) determined that this negative relationship was consistently significant $(P<0.05)$ from 1895 to 2010. Finally, Pearson's correlation coefficient was calculated between the Bear River gage and the SFC standard chronology for the period 1943-2010 $(r=0.82)$, which suggests that SFC is a reasonable proxy for the Bear River headwater gage.

\subsection{Reconstruction development}

A reconstruction model for the Bear River gage was built using simple linear regression with Bear River water-year MAF as the dependent variable, and the SFC standard chronology as the independent variable. We explored the standard, residual, and arstan chronologies as stream flow predictors. We also explored the use of $t+1$ and $t-1$ lags of SFC on stream flow data but neither contributed to any additional explanation of variance. Although the standard chronology had significant 1st-order autocorrelation (0.51), it also exhibited the highest correlation to the stream flow record, passed all tests for linear regression assumptions and therefore was used for all ensuing analysis. Linear regression model assumptions were evaluated by inspection of residual plots to ensure that there was no pattern in error variance. Normality of model residuals was evaluated graphically by examining a histogram, and tested statistically using the Kolmogorov-Smirnov test. An autocorrelation function of the residuals was examined visually, and the Durbin-Watson $d$ statistic was used to evaluate the assumption of independence in the predictor variable.

Pearson's correlation coefficient $(r)$, the coefficient of determination $\left(r^{2}\right)$, and adjusted coefficient of determination $\left(R^{2}\right)$ were used to evaluate model skill. We also calculated root-meansquared-error (RMSE) from the model as an indicator of variability in the reconstruction. Split calibration/verification was performed by splitting the gage record roughly in half and building independent linear models for the early (1943-1976) and late (1977-2010) periods and then reversing the time periods. The reduction of error (RE), an indicator of skill compared to the calibration-period mean, and the coefficient of efficiency (CE), an indicator of skill compared to the verification-period mean were used to assess the model. The ability of the full model to reproduce the mean and variance of the instrumental data was indicated by values of RE and CE greater than $\sim 0$ (Fritts, 1976). We also conducted a sign test to evaluate the fidelity of year-to-year changes in the reconstructed stream flow to the tree-ring predictor (Fritts, 1976).

\subsection{Reconstruction analysis}

Because direct comparisons between the instrumental data period used for model development and the longer reconstruction were not statistically appropriate, we focused instead on comparing variability in the Bear River reconstruction to its long-term mean. We limited our analysis of the reconstructed time series to the period where the expressed population signal (EPS) of the SFC chronology exceeded an arbitrary minimum threshold of ca. 0.8-0.85 Wigley et al., 1984. Linkages from the reconstruction to observations during the instrumental period are therefore limited by the strength and consistency of the model.

Annual wet and dry extremes were tabulated and ranked based on the $>97.5$ percentile and $<2.5$ percentile from the full reconstruction record (800-2010). Following the approach of Knight et al., 2010 we applied a smoother to the reconstructed stream flow time-series to accentuate lower-frequency events. Decadal-scale wet/dry episodes were identified after fitting cubic-smoothing spline with $25 \%$ frequency cut-off at wavelength of 10 years to the reconstructed time-series. Low-frequency departures above the reconstruction mean were interpreted as pluvials, and runs below the mean were interpreted as droughts. Extreme events were defined as those that exceeded one standard deviation of the reconstructed values $(1.781 \mathrm{cms})$, either above or below the reconstructed mean and were interpreted as extreme pluvials or droughts, respectively. For decadal episodes and extreme events we tabulated the magnitude (cumulative sum of the difference of smoothed stream flow from the mean during the run) and duration.

Lower-frequency patterns in stream flow variability (i.e., multidecadal and longer) were visually assessed using cubic-smoothing splines with a $50 \%$ frequency cut-off at wavelengths of 20 -years and 60-years applied to the reconstruction. These wavelengths were chosen based on previous climate research that indicated strong quasi-decadal and multi-decadal variability in the regional variability of wet/dry regimes (Wang et al., 2010, 2012). As the first millennium-length climate reconstruction for the northern Utah region, we conducted an adaptive multi-taper method to analyze the frequency domain using $3 \times 2$ pi tapers. We evaluated the results against a 95\% significance level.

\subsection{Climatology analysis}

To explore the climatic drivers of stream flow variability, we examined the circulation anomalies associated with the seasonal delivery of precipitation to the region and subsequently on stream flow. Monthly gridded precipitation compiled by the Climatic Research Unit (CRU) at 0.5-deg resolution (Jones et al., 2012) was utilized. Circulation anomalies were calculated using the Twentieth Century Reanalysis (V2) performed with the Ensemble Filter as described in Compo et al. (2011), which assimilates observed surface pressure and sea level pressure and sea surface temperature (SST) every six hours. The SST dataset used here was adopted from the NOAA Extended Reconstructed Sea Surface Temperature (SST) V3b monthly values (Smith et al., 2008; Xue et al., 2003).

To understand further the stream flow (and tree-ring) response to precipitation throughout the water year, we regressed the monthly CRU precipitation (from a box averaged within a $12 \mathrm{~km} \times 12 \mathrm{~km}$ domain surrounding the stream gage, i.e. the upper Bear River watershed) with (a) the reconstructed flow, (b) the gaged flow, and (c) their difference. A regression was done on the precipitation percent from normal (1971-2000 mean) for the previous year and the current year, and the percent difference was calculated to show the monthly anomaly that drives stream flow. We then constructed the regression maps of 250-h Pa geopotential height, a height important for understanding upper-level circulation known to drive precipitation delivery to topographically diverse northern Utah (Wang et al., 2010) and precipitation that correspond to a-c above, for the October-December and April-June seasons, respectively.

\section{Results}

\subsection{Reconstruction model}

Utah juniper tree-ring series from the SFC site exhibited a strong interseries correlation coefficient (0.806), and were highly correlated with both instrumental precipitation and stream flow, indicating that trees at this site respond to similar climate 
conditions and ought to be a reasonable hydroclimate proxy (data not shown). Similarly, two measures of year-to-year variability in ring-width, i.e., sensitivity, were relatively high; mean average sensitivity was 0.466 , and the Gini coefficient for the SFC standard chronology was 0.232 . Out of 19,064 crossdated rings, $177(0.928 \%)$ were locally absent. Based on a 25-year running window, overlapped by 12.5 year, the chronology EPS exceeded 0.8 in 793, and exceeded 0.85 from 818 to 2010 . The period from 800 to 2010 was interpreted in all subsequent results.

Because the strong variation displayed in ring width among Utah juniper at SFC was highly correlated with the Bear River headwater gage $(r=0.82)$, a parsimonious simple linear regression using only the SFC standard chronology as a predictor resulted in a reconstruction model that accounted for $67 \%$ of the variation in Bear River instrumental stream flow for the period 1943-2010 (Table 1, Fig. 2). Inspection of residual plots using the Kolmogorov-Smirnov test indicated that the residuals were normally distributed. An autocorrelation function plot of the residuals showed no significant first-order autocorrelation, and the Durbin-Watson test statistic fell within the range of non-rejection $(d=1.557, P<0.033)$, which indicated residuals were normal and validated that the predictor variable was independent.

Calibration and verification statistics indicated strong fidelity between the predictor and the predictand for both the early and late models (Table 1). Calibrating on the early period resulted in less predictive skill than calibrating on the later period (Table 1). RE and CE statistics were well above 0 , which indicated predictive skill for the calibration, verification, and full model periods (Table 1 ). The sign test was significant at the 0.01 level, and indicated that $82 \%$ of the time year-to-year changes in the direction of predicted flow followed that of the instrumental data, while $18 \%$ of the time they did not (Table 1 ). Like many hydroclimatic reconstructions, the model did not capture the variability in high years as well as the low years (Fig. 2). The reconstruction was unusual in that it was based on a single-tree chronology, which carried the advantage of parsimony; however, relied on the assumption that a single species/site displayed a consistent climatic response for $\sim 1200$ years. While this was born out by the calibration/verification statistics, results in this study should be interpreted with caution.

\subsection{Characteristics of reconstructed flow}

Over the past 1200 years Bear River stream flow has exhibited substantial annual, decadal, multi-decadal, and centennial-scale variability (Fig. 3). The spectral analysis revealed significant periodicity in the decadal, multi-decadal, and centennial-scales for the Bear River reconstruction (Fig. 4). Multi-decadal-scale variability was a recurrent feature of nearly the entire reconstruction (Fig. 3) and was statistically pronounced in the $\sim 7-8$ year range, $\sim 18-22$ year range, $\sim 30$ years, and $>50$ years (Fig. 4). Previously undocumented for the Wasatch Front region of the west, highly significant centennial-scale ( $\sim 100-200$-year) periodicity is evident for Bear River MAF (Fig. 4). The importance of low-frequency

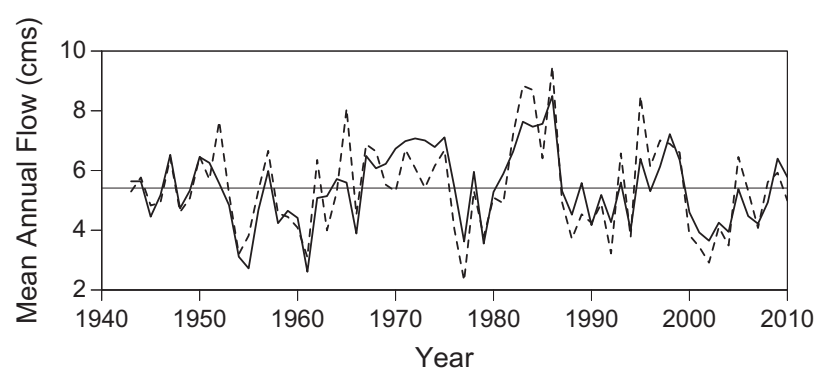

Fig. 2. Observed (dashed line) versus predicted (solid line) Bear River stream flow for the instrumental period (1943-2010). Horizontal line indicates instrumental mean water year flow $(5.412 \mathrm{cms})$. Linear regression model explained $67 \%$ of the variation in instrumental Bear River flow.

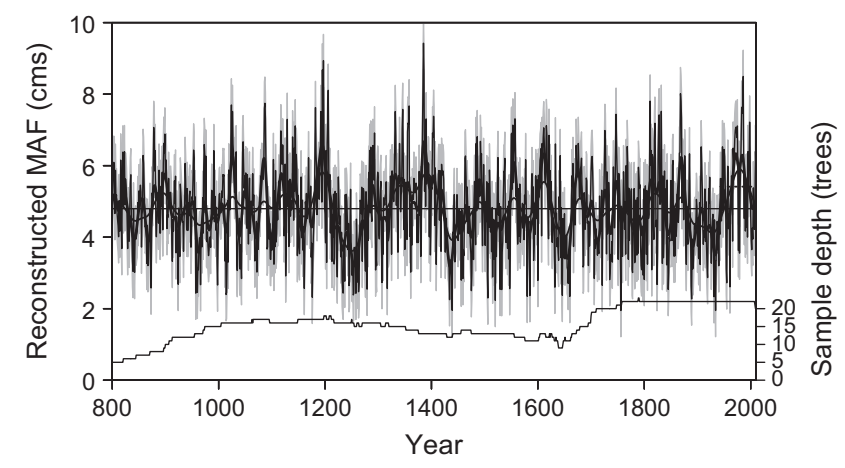

Fig. 3. Reconstructed Bear River stream flow from 800 to 2010 AD (thin black line), dark bold solid line cubic smoothing spline with $50 \%$ frequency cut-off at wavelength 20 years, light bold solid line cubic smoothing spline with $50 \%$ frequency at wavelength 60 years. Gray bands indicate $80 \%$ confidence interval calculated from the Bear River reconstruction model RMSE. Solid horizontal line is reconstructed MAF $(4.796 \mathrm{cms})$. Dashed horizontal line is instrumental MAF $(5.412 \mathrm{cms})$. Sample depth (number trees) for SFC indicated on the right.

variability was accentuated by a cubic smoothing spline (Fig. 3), which revealed nearly $\sim 70$ years of below average flow during the 13th century followed immediately by almost 100 years of above average flow conditions (Fig. 3).

Annual variability in reconstructed Bear River MAF ranged from 1.95 in 1756 to 9.42 in 1385 (Table 2). In contrast, instrumental variability of Bear River MAF ranged from 2.31 in 1977 to 9.48 in 1986. Although not part of the headwater gage instrumental record, three dry years occurred after the settlement of the region: 1934 was one of the driest years (ranked 2nd) for the entire 1200-yr period, 1889 was the 6th driest, and 1931 was the 9th driest. None of the driest years occurred during the instrumental record, In contrast, four of the wettest years were in the latter half of the 20th century (1983-1986). 1986 was the fourth wettest year, ranked behind events that occurred in the 12th and 14 th centuries (Table 2).

On inspection of the decadal-scale reconstruction there was a similar number of dry (39) and wet (37) episodes (Fig. 5). On

Table 1

Model skill statistics and calibration-verification results for the Bear River reconstruction.

\begin{tabular}{|c|c|c|c|c|c|c|c|}
\hline & $r$ & $R^{2}$ & Adj. $R^{2}$ & $\mathrm{RE}$ & $\mathrm{CE}$ & Sign test (hit/miss) & RMSE (cms) \\
\hline Calibrate (1943-1976) & 0.72 & 0.52 & 0.50 & 0.66 & 0.39 & & \\
\hline Calibrate (1977-2010) & 0.90 & 0.81 & 0.80 & 0.23 & 0.13 & & \\
\hline Full model & 0.82 & 0.68 & 0.67 & & & $54 / 12^{\mathrm{a}}$ & 0.8156 \\
\hline
\end{tabular}

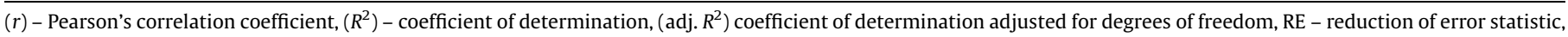

CE - coefficient of efficiency statistic, RMSE - root mean-squared error.

Full model: $1.9414+2.9048 *$ SFC.

a Sign test significant at the alpha $<0.01$ level (Fritts, 1976). 


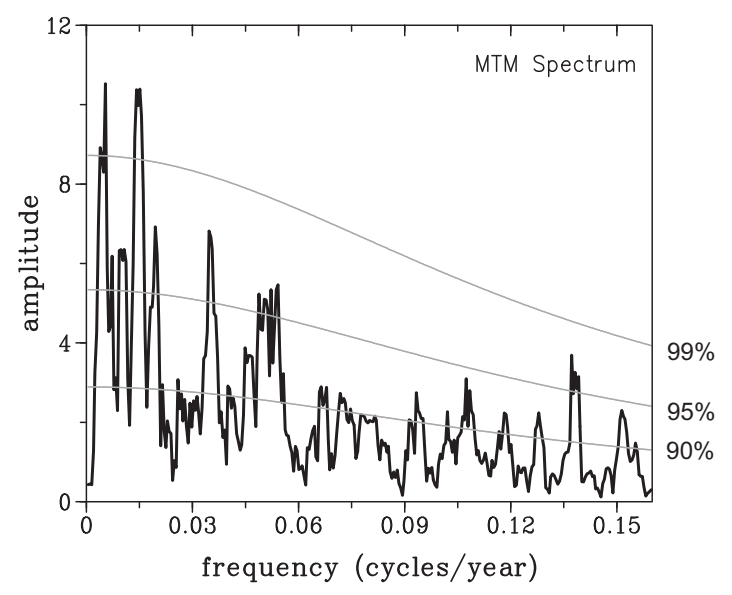

Fig. 4. Spectrum produced by adaptive multi-taper method of spectral analysis for the 800-2010 Bear River reconstructed stream flow. Gray contour lines indicated $99 \%, 95 \%$, and $90 \%$ confidence levels against a red noise background.

Table 2

Bear River stream flow (cms) values for ranked individual dry and wet years based on $<2.5$ percentile and $>97.5$ percentile, respectively for the reconstruction period ( 800 2010). Bold values indicate years within the instrumental record.

\begin{tabular}{|c|c|c|c|c|}
\hline Rank & Dry years & Value & Wet years & Value \\
\hline 1 & 1756 & 1.94 & 1385 & 9.42 \\
\hline 2 & 1934 & 1.94 & 1197 & 8.93 \\
\hline 3 & 1439 & 1.95 & 1195 & 8.67 \\
\hline 4 & 1520 & 2.23 & 1386 & 8.57 \\
\hline 5 & 1434 & 2.25 & 1986 & 8.49 \\
\hline 6 & 1889 & 2.27 & 1384 & 8.13 \\
\hline 7 & 1506 & 2.29 & 1206 & 8.10 \\
\hline 8 & 1176 & 2.31 & 1868 & 8.01 \\
\hline 9 & 1931 & 2.33 & 1811 & 7.80 \\
\hline 10 & 1660 & 2.34 & 1869 & 7.79 \\
\hline 11 & 1580 & 2.34 & 1087 & 7.74 \\
\hline 12 & 1585 & 2.36 & 1024 & 7.69 \\
\hline 13 & 1646 & 2.37 & 1358 & 7.66 \\
\hline 14 & 1253 & 2.38 & 1983 & 7.63 \\
\hline 15 & 1014 & 2.39 & 1182 & 7.62 \\
\hline 16 & 1254 & 2.42 & 1086 & 7.60 \\
\hline 17 & 1258 & 2.43 & 1346 & 7.57 \\
\hline 18 & 957 & 2.43 & 1985 & 7.56 \\
\hline 19 & 1234 & 2.43 & 1832 & 7.51 \\
\hline 20 & 1015 & 2.45 & 1026 & 7.51 \\
\hline 21 & 960 & 2.46 & 1332 & 7.51 \\
\hline 22 & 1263 & 2.47 & 1192 & 7.51 \\
\hline 23 & 1475 & 2.50 & 1984 & 7.46 \\
\hline 24 & 1532 & 2.53 & 1747 & 7.43 \\
\hline 25 & 1845 & 2.53 & 1828 & 7.41 \\
\hline 26 & 1529 & 2.54 & 1404 & 7.38 \\
\hline 27 & 1279 & 2.54 & 1193 & 7.36 \\
\hline 28 & 1233 & 2.55 & 1870 & 7.33 \\
\hline 29 & 1547 & 2.56 & 1088 & 7.31 \\
\hline 30 & 1317 & 2.56 & 1557 & 7.30 \\
\hline 31 & 1161 & 2.56 & 1390 & 7.30 \\
\hline
\end{tabular}

average, decadal-scale droughts lasted 17 years, while decadal pluvials lasted 15 years. The thirty most intense drought and pluvial episodes, ranked by duration, were tabulated in Table 3. The most extensive decadal-scale drought lasted 71 years spanning from 1210 to 1281 , and its magnitude was nearly twice that of the 2nd largest drought that ended in 1462 (Table 3). Similarly, the largest pluvial occurred long before the instrumental record, ending in 1424, 46 years in duration. The 2 nd largest pluvial event occurred entirely during the instrumental period, spanning the 39 years from $\sim 1961$ to 2000 (Table 3 ).

Extreme decadal events were more asymmetrically distributed, with 8 dry events and 15 wet events. Duration of extreme drought

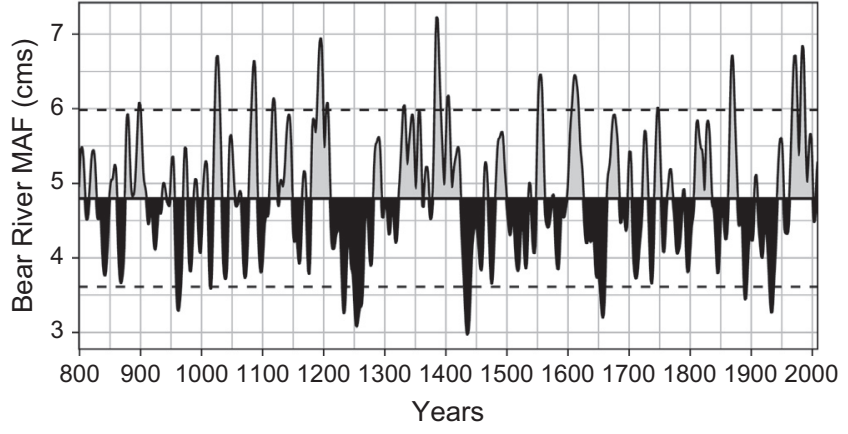

Fig. 5. Reconstructed Bear River decadal-scale drought (black) and pluvial (gray) periods from cubic smoothing spline with frequency response of $25 \%$ at wavelength 10 years. Dashed lines indicate 1 SD from reconstruction mean. See Table 3 for ranked dry and wet periods.

Table 3

Ending year, magnitude, and duration of decadal-scale (smoothed reconstruction) drought and pluvial episodes ranked by magnitude. Bold values indicate observations during the instrumental period (1943-2010).

\begin{tabular}{|c|c|c|c|c|c|}
\hline \multicolumn{3}{|c|}{ Dry periods } & \multicolumn{3}{|c|}{ Wet periods } \\
\hline End year & Magnitude & Duration & End year & Magnitude & Duration \\
\hline 1281 & -58.38 & 71 & 1424 & 39.07 & 46 \\
\hline 1462 & -32.72 & 38 & 2000 & 38.53 & 39 \\
\hline 1663 & -30.88 & 38 & 1210 & 35.45 & 31 \\
\hline 1942 & -23.60 & 32 & 1361 & 26.74 & 39 \\
\hline 1535 & -17.80 & 36 & 1625 & 24.73 & 27 \\
\hline 1905 & -16.51 & 28 & 909 & 17.97 & 35 \\
\hline 970 & -14.58 & 15 & 1835 & 17.92 & 29 \\
\hline 1721 & -11.92 & 17 & 1033 & 16.24 & 14 \\
\hline 849 & -10.97 & 22 & 1877 & 15.47 & 15 \\
\hline 1862 & -10.68 & 27 & 1091 & 15.26 & 14 \\
\hline 874 & -10.33 & 13 & 1561 & 14.13 & 13 \\
\hline 1110 & -9.64 & 19 & 1683 & 13.42 & 20 \\
\hline 1165 & -8.88 & 17 & 1148 & 10.99 & 21 \\
\hline 1598 & -8.74 & 22 & 1499 & 10.26 & 18 \\
\hline 1806 & -8.39 & 15 & 1124 & 10.16 & 14 \\
\hline 1077 & -8.30 & 13 & 1752 & 7.87 & 11 \\
\hline 1481 & -8.21 & 13 & 1294 & 7.61 & 13 \\
\hline 1043 & -8.11 & 10 & 1953 & 5.41 & 11 \\
\hline 935 & -7.33 & 26 & 1054 & 5.11 & 11 \\
\hline 1741 & -7.15 & 10 & 1731 & 4.96 & 10 \\
\hline 1787 & -7.11 & 16 & 827 & 4.55 & 11 \\
\hline 1322 & -6.94 & 28 & 809 & 4.13 & 10 \\
\hline 1019 & -6.59 & 9 & 861 & 3.09 & 12 \\
\hline 987 & -6.54 & 11 & 976 & 2.88 & 6 \\
\hline 1179 & -5.15 & 8 & 1704 & 2.61 & 6 \\
\hline 1548 & -4.35 & 9 & 1010 & 2.50 & 8 \\
\hline 1762 & -3.98 & 10 & 955 & 2.39 & 7 \\
\hline 1002 & -3.98 & 10 & 1372 & 2.18 & 8 \\
\hline 1962 & -3.50 & 9 & 1771 & 2.04 & 9 \\
\hline 1698 & -3.49 & 15 & 1468 & 2.01 & 6 \\
\hline
\end{tabular}

was 7 years on average, and 6 years for extreme wet periods. While the most extreme wet/dry periods shared similar magnitude (Table 4), pluvials had larger deviations from the mean than droughts, although the duration was quantitatively similar between the two (Table 4, Fig. 5). Multiple extreme droughts occurred in the mid-1200s, mid-1400s, and mid-1600s, which exhibited the largest deviations from mean conditions for the entire record. The fourth most extreme drought occurred after the settlement period, covered the period from 1931 to 1936 , and became the first 'drought-of-record' for Bear River Management. The three most extreme pluvials were centered on the late-1300s, late-1100s, and early 1600s (Table 4, Fig. 5). Noteworthy are the fourth and fifth most extreme pluvials that occurred during the instrumental period. They extended from 1968 to 1975 and then again from 1981 to 1987, the latter caused 
Table 4

Ending year, magnitude, and duration for extreme ( $> \pm 1$ reconstruction SD) decadalscale drought and pluvial episodes. Bold indicates observations within the instrumental record (1943-2010).

\begin{tabular}{ccccccc}
\hline \multicolumn{2}{c}{ Dry periods } & \multicolumn{5}{l}{ Wet periods } \\
\cline { 1 - 2 } \cline { 5 - 6 } End year & Magnitude & Duration & & End year & Magnitude & Duration \\
\hline 1263 & -21.19 & 14 & 1391 & 18.60 & 10 \\
1440 & -15.88 & 10 & 1198 & 16.17 & 9 \\
1660 & -11.38 & 8 & 1616 & 14.85 & 10 \\
1936 & -8.48 & 6 & $\mathbf{1 9 7 5}$ & $\mathbf{1 3 . 1 5}$ & $\mathbf{8}$ \\
965 & -8.47 & 6 & $\mathbf{1 9 8 7}$ & $\mathbf{1 1 . 8 7}$ & $\mathbf{7}$ \\
1235 & -7.10 & 5 & 1029 & 11.75 & 7 \\
1892 & -5.18 & 4 & 1872 & 11.26 & 7 \\
1015 & -1.20 & 1 & 1088 & 9.83 & 6 \\
& & & 1557 & 9.24 & 6 \\
& & & 1405 & 5.14 & 4 \\
& & & 1119 & 3.89 & 3 \\
& & & 899 & 2.53 & 3 \\
& & & 1206 & 2.51 & 2 \\
& & & 1332 & 2.46 & 2 \\
& & & & 1.21 & 1 \\
\hline
\end{tabular}

widespread flooding by the Great Salt Lake. Decadal-scale wet periods and extreme pluvial events characterized the latter half of the 20 th century as the 2 nd wettest 50 years in over 1200 years.

\subsection{Seasonality and dynamics of stream flow}

Regressions between gridded precipitation and the tree-ringbased reconstruction (Fig. 6a) and gaged stream flow (Fig. 6b) were markedly similar. The largest atmospheric precipitation drivers occurred in two seasons, one in the October-December in the previous year and the other, to a lesser extent, during the growing season of April-June. The difference between the reconstructed flow and gaged flow indicated that the previous November-December season featured the largest disagreement, which suggested that early-winter precipitation may not be captured as well by tree rings compared to spring precipitation.
Regression maps of 250-h Pa geopotential height and precipitation for the October-December season (associated with the peak seasonal response shown in Fig. 6a-c) exhibited low pressure over the Bear River watershed, which redirected the jet stream and associated synoptic waves toward northern Utah (Fig. 6d-f). The circulation and precipitation anomalies between the reconstructed and gaged stream flow (Fig. 6d and e) were strikingly similar, which we expected. The early winter anomalies were considerably stronger than those during the April-June season (Fig. 6g-i). Also noteworthy was the distribution of precipitation anomalies, which covered the central western U.S. across the central Great Plains, a connection in precipitation anomalies between the two regions noted in Wang et al., 2014. The difference in circulation anomalies between gaged and reconstructed stream flows was much stronger in early winter (previous OND) than in the subsequent spring (Fig. $6 \mathrm{f}$ and i), which suggested the more important role of early winter precipitation anomalies on stream flow than on tree growth.

\section{Discussion}

\subsection{Utah juniper-based reconstruction model}

Against conventional wisdom, we demonstrate that Utah juniper can be crossdated and can in fact be used for robust climate reconstruction. In this case Utah juniper serves as an excellent proxy for stream flow in northern Utah, and from the SFC ringwidth indices we have produced a model with very high skill for the Utah-Wyoming gaging station of the Bear River. Although only one Utah juniper site was used in this study, the ability to crossdate this species in the region is not unique (DeRose, unpublished data). Furthermore, the longevity and level of preservation of remnant wood for this species enabled the development of the first millennia-scale reconstruction of stream flow for the region, and allowed us to examine wet and dry events 650 years further into the past (800-1450) than was previously possible for the Wasatch
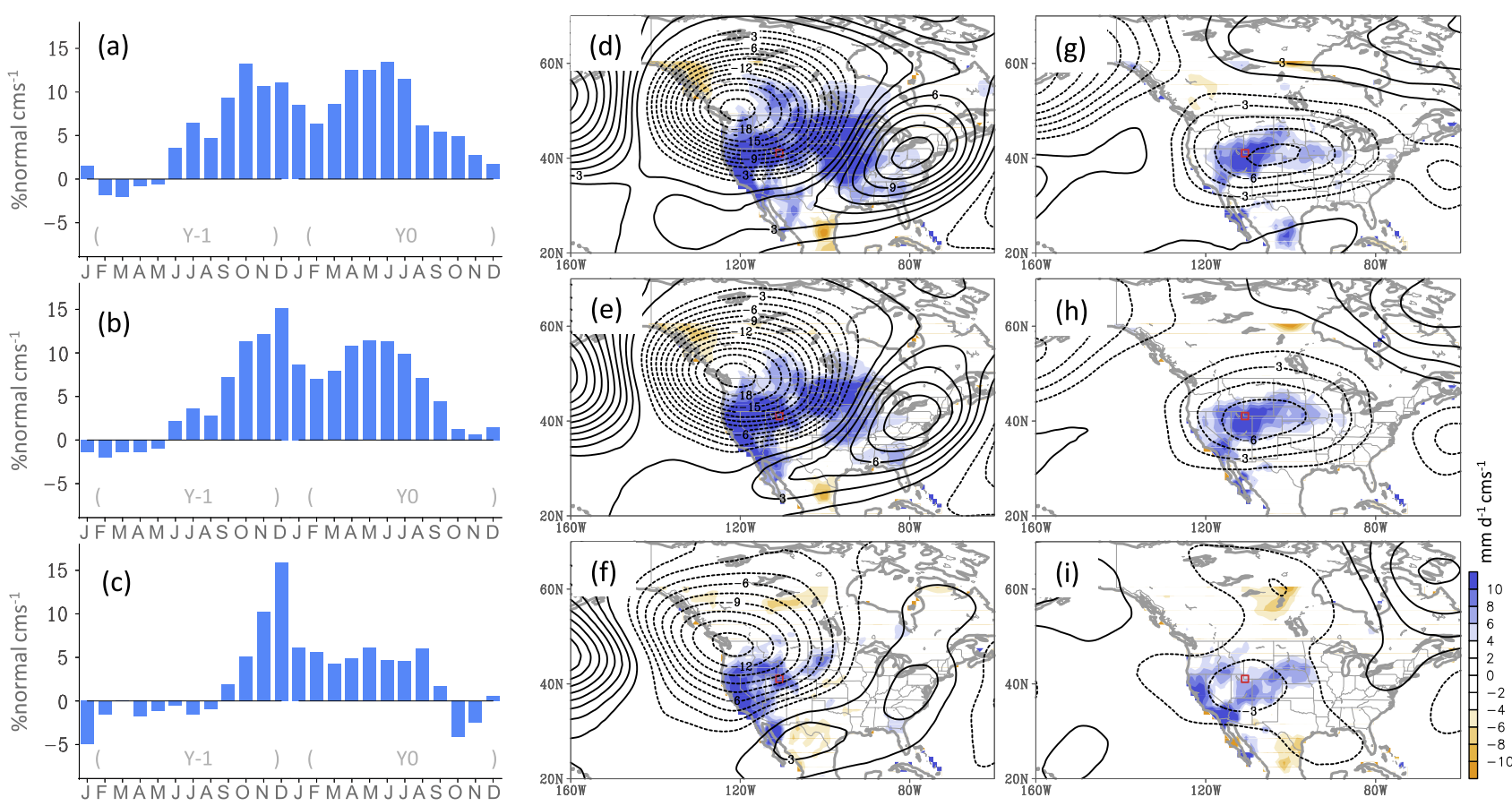

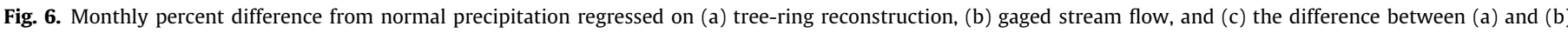

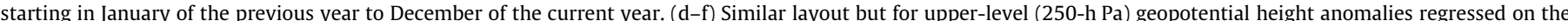

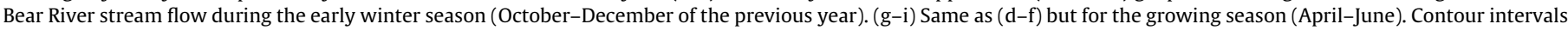
are $1.5 \mathrm{~m}$ with the zero contours omitted. 
Front. This advancement facilitates the evaluation of hydroclimatic variation across watersheds in northern Utah and across the Intermountain West. Consequently, we can now quantify the inherent centennial, multi-decadal, and quasi-decadal variability of this region. Taken collectively these modes are thought to comprise the most important drivers of the delivery of precipitation in the form of winter snow pack to one of the wettest regions of Utah (Gillies et al., 2012).

\subsection{Modes of stream flow variability}

\subsubsection{Annual-scale variability}

Annual correspondence between the Bear River reconstruction and the other recent reconstructions from the Wasatch Front region was modest for the shared reconstruction period (16052010) when compared to the instrumental period (1943-2010, Table 5). Higher agreement between the Weber and Bear reconstructions was expected, as the headwaters of these rivers are directly adjacent to one another in the western Uinta Mountains. The Bear River drains the north slope of the Uinta Mountains and the Weber drains the northwest flank. Whereas the headwaters of the Logan River drain the northern tier of the Wasatch Range (i.e., Bear River Range), and the Great Salt Lake integrates runoff from the Uinta, Wasatch, and Bear River ranges. While fine-scale spatial differences between these reconstructions might help to identify droughts in local watersheds versus more regional events, it is likely they also indicate species-specific variability in climate response that was only partly accounted for in each reconstruction model. The most extreme individual dry years that we find in each of the reconstructions, were also consistent with the reconstruction of Upper Colorado River Basin headwater tributaries (UCRB Gray et al., 2011), although some years such as 1934, 1889, 1756, and 1580 appear to have been far worse over the Wasatch Range.

\subsubsection{Decadal-scale variability}

Comparisons at the decadal-scale of Bear River stream flow to other hydroclimate reconstructions for the Wasatch Front revealed general agreement (Fig. 7). Perhaps most prominent across these four reconstructions was the similarity in magnitude of the early 1600s pluvial, followed by the abrupt transition to the third largest drought during the Bear River reconstruction, the mid-1600s drought. This drought was also implicated as the driest 14-year period in the Weber River reconstruction with only one year above the instrumental mean (Bekker et al., 2014), and likely reflects the most severe drought over the last $\sim 400$ years for the Snake River headwaters (Wise, 2010). Reconstructions to the east in the Uinta Mountains (MacDonald and Tingstad, 2007), to the south on the Tavaputs Plateau (Knight et al., 2010), and to the west in the Great Basin (Strachan et al., 2011) also documented a severe drought during this time period.

Our analysis of decadal-scale drought revealed a remarkable $\sim 70$-year below-average stream flow episode from $\sim 1210$ to 1281 that was hitherto unknown for the Wasatch Front. During this 70 -year period the Bear River reconstruction revealed below-mean flows for 16 consecutive years (1249-1265), and 23 years with only one year above the mean (1242-1265). For

\section{Table 5}

Correlation matrix for instrumental (1943-2010, upper right) and reconstructed (1605-2010, lower left) time periods for important Wasatch Front paleoclimate reconstructions.

\begin{tabular}{lllll}
\hline & Bear River & Great Salt Lake & Logan River & Weber River \\
\hline Bear River & - & 0.63 & 0.79 & 0.94 \\
Great Salt Lake & 0.47 & - & 0.72 & 0.68 \\
Logan River & 0.51 & 0.41 & - & 0.87 \\
Weber River & 0.53 & 0.61 & 0.43 & - \\
\hline
\end{tabular}

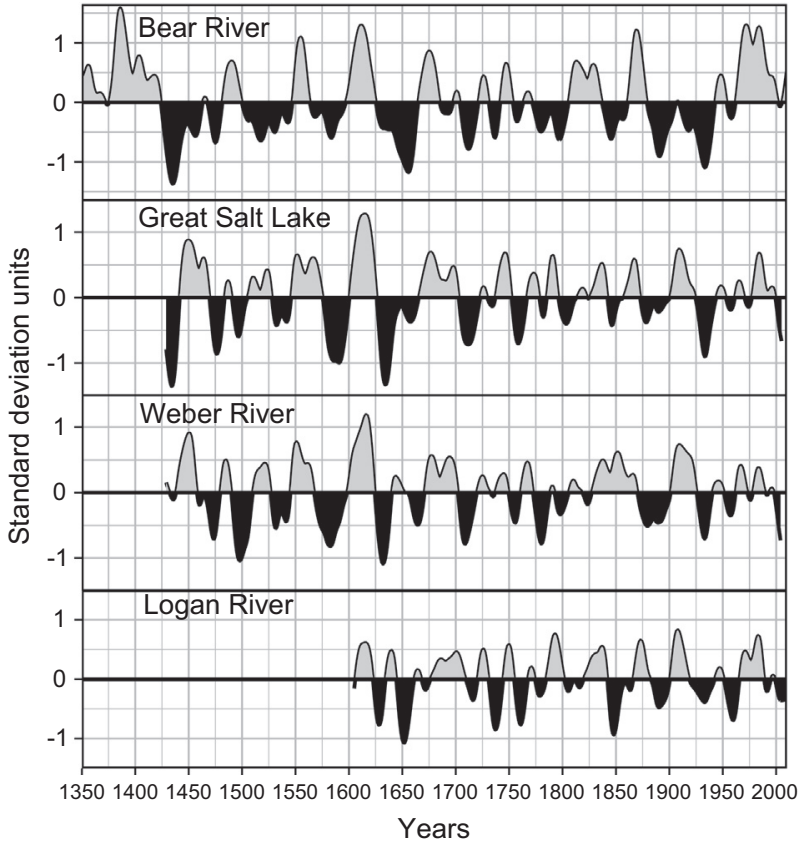

Fig. 7. Comparison between the Bear River and other Wasatch Front hydroclimate reconstructions. Time-series converted to standard deviation units and smoothed using a 20 -year spline with a $50 \%$ frequency cut-off.

additional context consider that reconstruction mean Bear River MAF $(4.796 \mathrm{cms})$ is substantially lower than the instrumental mean MAF of $5.412 \mathrm{cms}$ (Fig. 3). This prolonged drought episode is situated squarely in what has been termed the Medieval Warm Period (MWP, 900-1300 CE, Lamb, 1965), a period characterized by severe western droughts (Cook et al., 2004; Meko et al., 2007). Not surprisingly, this drought episode was also ranked as the highest magnitude in the entire Bear River reconstruction. Southeast of SFC, on the Tavaputs Plateau Knight et al. (2010) identified an extensive episode of below average precipitation during the mid1200s. While Meko et al. (2007), found the largest drought anomaly of the past 1200 years occurred during the 12th century, the Bear River reconstruction revealed its largest drought during the 13 th century. The next most severe droughts, in the mid-1400s and mid-1600s, were nearly half the magnitude and of a markedly shorter duration (38 years) than the driest episode.

\subsection{Regional comparisons}

Most paleoclimate studies in the West have documented an early 20th century pluvial e.g., (Barnett et al., 2010; Watson et al., 2009; Wise, 2010), with the exception of Strachan et al. (2011), who found little evidence for a wet period in Spring Valley, Nevada. While the Bear River reconstruction exhibited a minor peak in high frequency flow early in the 20th century, when examined at lower frequencies (Figs. 3 and 4), this period is barely significant and was dwarfed by the mid-1800s and the late-1900s wet episodes. Numerous other reconstructions documented the mid-1800s event e.g., (Barnett et al., 2010; Gray et al., 2004; Watson et al., 2009), and it is likely that this pluvial was responsible for high Great Salt Lake levels in the latter part of the 19th century (DeRose et al., 2014). Similarly, many studies including this one, have documented an extremely wet 20th century, however, the Bear River reconstruction suggests that site or regional differences may dictate whether it was the first half, second half, or entire 20th century that experienced anomalously wet conditions. Because instrumental data for the Bear River began in 1943, PRISM 
data for the period 1895-2010 associated with the SFC site were examined for evidence of the early 20th century pluvial. Interestingly, the PRISM data confirmed the general pattern documented in the reconstruction, a much wetter latter-half of the 20th century compared to the first half (data not shown).

Besides the recent Wasatch Front reconstructions, the closest stream flow reconstruction is for the Ashley Creek drainage on the south slope of the Uinta Mountains. While Ashley Creek is located close to the Bear River, Carson and Munroe (2005) noted that the Ashley Creek flow was only modestly correlated with the Bear River gage (0.48). There are at least two reasons for such limited agreement from nearly adjacent Uinta watersheds. First, the Wasatch and western Uinta Mountains act as a barrier that creates a prominent rain shadow to winter time westerly storm tracks, resulting in a substantial difference of around $400 \mathrm{~mm}$ (Munroe, 2006) between instrumental precipitation from the western and eastern Uinta Mountains. Second, the southern and eastern flanks of the Uinta Mountains more reliably receive moisture and humidity associated with the North American Monsoon (Shaw and Long, 2007) than does the Wasatch Front, which is much less influenced by the Monsoon (Mock, 1996). Regardless, of the limited relationship in year-to-year variability, the larger synoptic climatology for this region of the West is evident based on the similarities in low-frequency wet/dry cycles among the Bear and the Green River (Barnett et al., 2010), the Uinta Basin precipitation (Gray et al., 2004), further to the southeast on the Colorado Plateau (Gray et al., 2011), and to the northeast in Wyoming (Watson et al., 2009).

\subsection{Circulation anomalies and Bear River stream flow}

We compared Bear River gaged stream flow with the hemispheric stream function at $250 \mathrm{~h} \mathrm{~Pa}$ and with SST anomalies (Fig. 8a), and as for precipitation, only a weak relationship with ENSO is evident, in the form of a weak cold SST anomaly region in the central-western equatorial Pacific. Regardless, this weak SST anomaly is associated with rather strong negative anomalies of precipitation to the east of Papua New Guinea (Fig. 8b). This pattern corresponds to a short-wave train in the upper troposphere that emanates from the western tropical Pacific and exerts down-stream influence on precipitation delivery to western North America, that is likely important for ring-width increment on moisture sensitive species such as Utah juniper. For example, the wave-train pattern in the upper-level circulation is consistent with that found by Wang et al. (2010) that caused the Great Salt Lake level to increase (and fall) periodically, and by Kalra et al. (2013) who found that it modulated the Gunnison and San Juan River Basins.

That the early winter (OND) circulation anomalies were distinctly stronger than the spring season, for both the tree-ring reconstruction and the gaged flow (Fig. 6), paired with the robust short-wave pattern in early winter (Fig. 8), indicated a prominent source of atmospheric teleconnection. This observation furthers our growing understanding of non-ENSO-based drivers of precipitation delivery to northern Utah. These results also suggest that our stream flow reconstruction could, at least in part, be improved by a better characterization of early winter precipitation. The fate of this early snowpack may be either to melt out or evaporate before it can accumulate into the winter snowpack that ultimately contributes to spring runoff and soil moisture. If the pronounced influence of the previous winter precipitation on tree-ring chronologies could be quantified, it could help improve our regional reconstruction models and our understanding of hydroclimatology for this region.

\subsection{Implications for Bear River stream flow management}

Stream flow from the Bear River is used to provide water to three states and multiple corporate and municipal interests in a variety of sectors that include agriculture, power generation, and environmental concerns (http://waterrights.utah.gov/techinfo/ bearrivc/history.html). The long-term picture of stream flow variability that we provide with the Bear River reconstruction is of great importance for water development and conservation. While we used a headwater gage to reconstruct stream flow, Pearson's correlation coefficients showed highly significant relationships between the UT-WY gage and other downstream gages (Table 6). It is important, however, to put the instrumental record in context. Ranked as the second largest magnitude pluvial event in the 1200year record, the late-20th century wet period (1963-2000) fell entirely within the instrumental record, strongly suggesting that current water management impression of available Bear River flow is biased toward higher flow. A similar issue was shown clearly by Stockton and Jacoby (1976) to result in the over-appropriation of water resource for the Colorado River, because estimates of MAF were based on a truly anomalously wet 30 -year period as demonstrated by a multi-centennial tree-ring reconstruction of MAF.
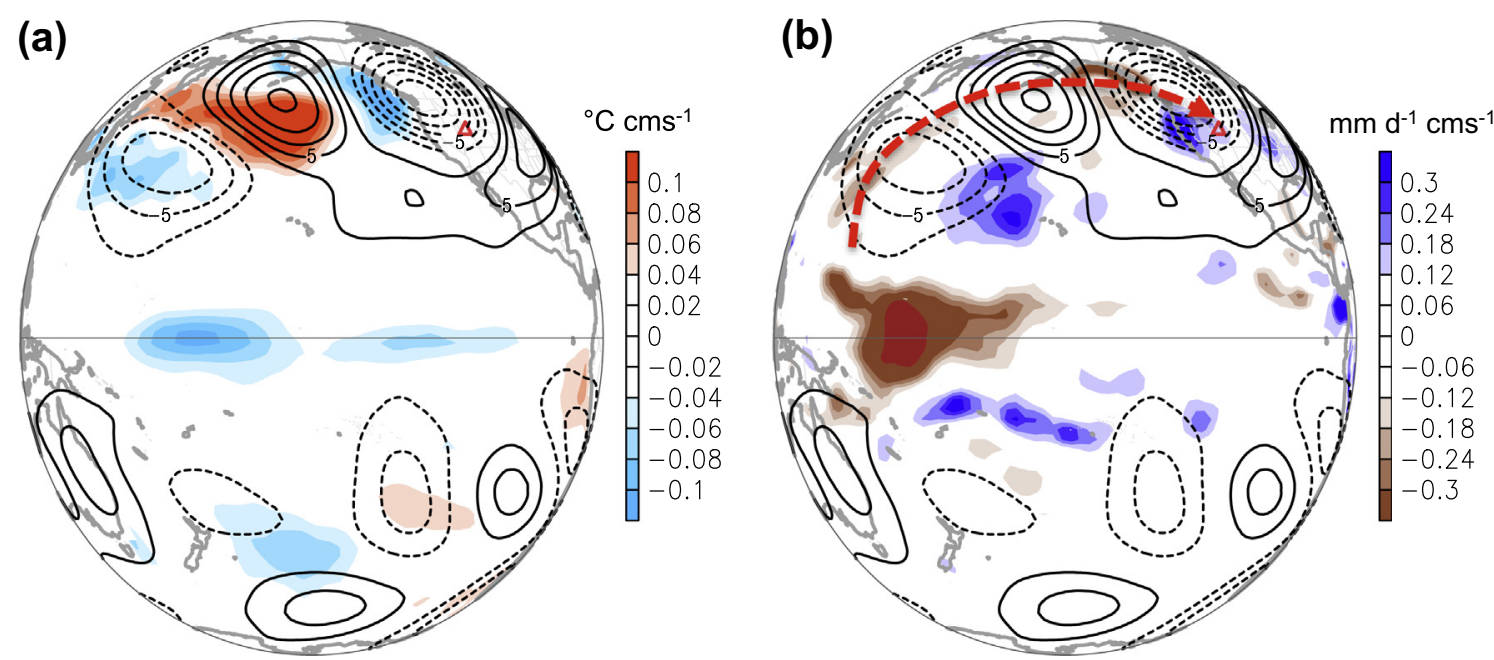

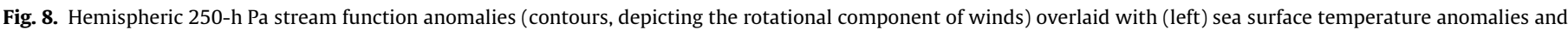

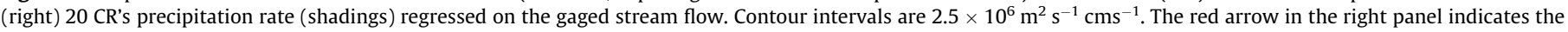
short-wave train emerging from the western tropical Pacific. 
Table 6

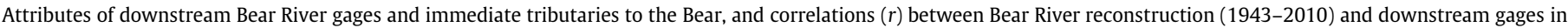
order of drainage area.

\begin{tabular}{|c|c|c|c|c|c|c|}
\hline USGS gage name (number) & $\begin{array}{l}\text { Location (easting- } \\
\text { northing) }\end{array}$ & $\begin{array}{l}\text { Elevation } \\
(\mathrm{m} \text { asl })\end{array}$ & $\begin{array}{l}\text { Drainage area } \\
\left(\mathrm{km}^{-2}\right)\end{array}$ & $\begin{array}{l}\text { Period of } \\
\text { record }\end{array}$ & $\begin{array}{l}\text { Missing data } \\
\text { (\# years) }\end{array}$ & $(r)$ \\
\hline Smith's Fork (Bear River tributary) (10032000) & $42^{\circ} 17^{\prime} 36^{\prime \prime} \mathrm{N} 110^{\circ} 52^{\prime} 18^{\prime \prime} \mathrm{W}$ & 2027 & 427 & 1943-2013 & 0 & 0.72 \\
\hline Smith's Woodruff, UT (10020100) & $41^{\circ} 26^{\prime} 04^{\prime \prime} \mathrm{N} 111^{\circ} 01^{\prime} 01^{\prime \prime} \mathrm{W}$ & 1967 & 1955 & $1962-2013$ & 0 & 0.85 \\
\hline Smith's Cokeville, WY (10038000) & $42^{\circ} 07^{\prime} 36^{\prime \prime} \mathrm{N} 110^{\circ} 58^{\prime} 21^{\prime \prime} \mathrm{W}$ & 1871 & 6338 & 1955-2013 & 2 & 0.81 \\
\hline Border, WY (10039500) & $42^{\circ} 12^{\prime} 40^{\prime \prime} \mathrm{N} 111^{\circ} 03^{\prime} 11^{\prime \prime} \mathrm{W}$ & 1845 & 6423 & 1938-2013 & 4 & 0.79 \\
\hline Pescadero, ID (10068500) & $42^{\circ} 24^{\prime} 06^{\prime \prime} \mathrm{N} 111^{\circ} 21^{\prime} 22^{\prime \prime} \mathrm{W}$ & 1814 & 9596 & $1923-2013$ & 15 & 0.67 \\
\hline ID-UT state line (10092700) & $42^{\circ} 00^{\prime} 47^{\prime \prime} \mathrm{N} 111^{\circ} 55^{\prime} 14^{\prime \prime} \mathrm{W}$ & 1347 & 12,650 & 1971-2013 & 0 & 0.79 \\
\hline Corinne, UT (10126000) & $41^{\circ} 34^{\prime} 35^{\prime \prime} \mathrm{N} 112^{\circ} 06^{\prime} 00^{\prime \prime} \mathrm{W}$ & 1282 & 18,205 & 1950-2013 & 6 & 0.75 \\
\hline
\end{tabular}

Management of Bear Lake water reserves serves as an example of the possible implications of severely reduced stream flow on water use. Although not naturally part of the Bear River channel during historic times, but see Kaufman et al. (2009), Bear Lake has been modified to act as a reservoir for the Bear River. As a result Bear Lake level fluctuations have been used to indicate extended drought conditions (Endter-Wada et al., 2009). Since the development of Bear Lake to augment storage of Bear River water there have been two 'droughts-of-record' - the first 1936, and the second the period 2000-2004 (Endter-Wada et al., 2009). Not surprisingly, 1936 corresponds closely to the 4th driest extreme drought tabulated in this study (Table 4). However, the use of 2004, or the 2000-2004 drought period as a new drought benchmark would be problematic, as neither of these events fell within our ranking scheme (Tables 2-4, and Fig. 5). The ability of local communities to work together to forestall drastic water shortages is reassuring (Welsh et al., 2013), as they are likely to be challenged with much more substantial droughts in the future. Rapidly growing populations in the Wasatch Front Counties, to whom the Bear River has a future delivery obligation, in combination with likely increasing variability in precipitation delivery due to increased temperatures associated with climate warming (Gillies et al., 2012), are going to be pressing challenges for water management. Maintaining high expectations for future availability of Bear River flow could have catastrophic consequence if, for example, a prolonged period of drought is encountered.

\section{Acknowledgements}

The Wasatch Dendroclimatology Research Group (WADR) was crucial for funding and guidance associated with this project. Special thanks go to Le Canh Nam, Nguyen Thiet, Justin Britton, Slaton Wheeler, Calli Nielsen, Hannah Gray, and Jackson Deere for their field and lab help. Funding was provided by the U.S. Bureau of Reclamation, WaterSmart Grant No. R13AC80039. We would like to thank Jennefer Parker on the Logan Ranger District of the UintaWasatch-Cache National Forest, Karl Fuelling on the Minidoka Ranger District, Sawtooth National Forest, and Charley Gilmore for permission to sample. We acknowledge the comments of two anonymous reviewers that greatly improved the paper. This paper was prepared in part by an employee of the US Forest Service as part of official duties and is therefore in the public domain. Utah State University, Agricultural Experiment Station, approved as journal paper no. 8771. Lamont-Doherty Earth Observatory contribution no. 7864 .

\section{References}

Allen, E.B., Rittenour, T.M., DeRose, R.J., Bekker, M.F., Kjelgren, R., Buckley, B.M. 2013. A tree-ring based reconstruction of Logan River streamflow, northern Utah. Water Resour. Res. 49, 8579-8588. http://dx.doi.org/10.1002/ 2013WR014273.
Axelson, J.N., Sauchyn, D.J., Barichivich, J., 2009. New reconstructions of streamflow variability in the South Saskatchewan River Basin from a network of tree ring chronologies, Alberta, Canada. Water Resour. Res. 45, W09422. http:// dx.doi.org/10.1029/2008WR007639.

Barnett, F.A., Gray, S.T., Tootle, G.A., 2010. Upper Green River Basin (United States) streamflow reconstructions. J. Hydrol. Eng. 15, 567-579.

Bekker, M.F., Heath, D.M., 2007. Dendroarchaeology of the Salt Lake Tabernacle, Utah. Tree-Ring Res. 63, 95-104. http://dx.doi.org/10.3959/1536-1098-63.2.95.

Bekker, M.F., DeRose, R.J., Buckley, B.M., Kjelgren, R.K., Gill, N.S., 2014. A 576-year Weber River streamflow reconstruction from tree rings for water resource risk assessment in the Wasatch Front, Utah. J. Am. Water Resour. Assoc. 50, 13381348. http://dx.doi.org/10.1111/jawr.12191.

Biondi, F., Qeadan, F., 2008a. A theory-driven approach to tree-ring standardization: defining the biological trend from expected basal area increment. Tree-Ring Res. 64, 81-96. http://dx.doi.org/10.3959/2008-6.1.

Biondi, F., Qeadan, F., 2008b. Inequality in paleorecords. Ecology 89, 1056-1067.

Biondi, F., Waikul, K., 2004. DENDROCLIM2002: a C++ program for statistical calibration of climate signals in tree-ring chronologies. Comput. Geosci. 30, 303-311.

Bunn, A.G., 2008. A dendrochronology program library in $R$ (dplR). Dendrochronologia 26, 115-124.

Carson, E.C. Munroe, J.S., 2005. Tree-ring based streamflow reconstruction for Ashley Creek, northeastern Utah: implications for palaeohydrology of the southern Uinta Mountains. The Holocene 15, 602-611.

Compo, G.P. et al., 2011. The twentieth century reanalysis project. Quart. J. R. Meteorol. Soc. 137, 1-28.

Cook, E.R., Briffa, K.R., Meko, D.M., Graybill, A., Funkhouser, G., 1995. The 'segment length curse' in long tree-ring chronology development for palaeoclimatic studies. The Holocene 5, 226-237. http://dx.doi.org/10.1177/ 095968369500500211.

Cook, E.R., Woodhouse, C.A., Eakin, C.M., Meko, D.M., Stahle, D.W., 2004. Long-term aridity changes in the eastern United States. Science 306, 1015-1018. http:// dx.doi.org/10.1126/science.1102586.

Cook, E.R., Seager, R., Cane, M.A., Stahle, D.W., 2007. North American drought: reconstructions, causes, and consequences. Earth-Sci. Rev. 81, 93-134.

Cook, B.I., Seager, R., Miller, R.L., 2011. On the causes and dynamics of the early twentieth-century North American pluvial. J. Clim. 24, 5043-5060. http:// dx.doi.org/10.1175/2011JCLI4201.1.

DeRose, R.J., Wang, S.-Y., Buckley, B.M., Bekker, M.F., 2014. Tree-ring reconstruction of the level of Great Salt Lake, USA. The Holocene. http://dx.doi.org/10.1177/ 0959683614530441

Douglas, J.L., Bowles, D.S., James, W.R., Canfield, R.V., 1979. Estimation of Water Surface Elevation Probabilities and Associated Damages for the Great Salt Lake. Report Paper 330.

Douglass, A.E., 1941. Crossdating in dendrochronology. J. Forest. 39, 825-831.

Division of Water Resources, State of Utah, 2004. Bear River Basin: Planning for the Future.

Endter-Wada, J., Selfa, T., Welsh, L.W., 2009. Hydrologic interdependencies and human cooperation: the process of adapting to droughts. Weather Clim. Soc. 1, 54-70.

Fritts, H.C., 1976. Tree Rings and Climate. Academic Press, N.Y.

Fritts, H.C., Smith, D.G., Stokes, M.A., 1965. The biological model for paleoclimatic interpretation of Mesa Verde tree-ring series. Memoirs Soc. Am. Archaeol., 101121 http://dx.doi.org/10.2307/25146673.

Gillies, R.R., Chung, O.-Y., Wang, S.-Y., Kokoszka, P., 2011. Incorporation of Pacific SSTs in a time series model toward a longer-term forecast for the Great Salt Lake elevation. J. Hydrometeorol. 12, 474-480.

Gillies, R.R., Wang, S.-Y., Booth, M.R., 2012. Observational and synoptic analyses of the winter precipitation regime change over Utah. J. Clim. 25, 4679-4698.

Gray, S.T., Jackson, S.T., Betancourt, J.L., 2004. Tree-ring based reconstructions of interannual to decadal scale precipitation variability for northeastern Utah since 1226 A.D. J. Am. Water Resour. Assoc. 40, 947-960.

Gray, S.T., Lukas, J.J., Woodhouse, C., 2011. Millennial-length records of streamflow from three major upper Colorado river tributaries. J. Am. Water Resour. Assoc. 47, 702-712.

Hidalgo, H.G., Dracup, J.A., MacDonald, G.M., King, J.A., 2001. Comparison of tree species sensitivity to high- and low-extreme hydroclimatic events. Phys. Geogr. $22,115-134$. 
Holmes, R.L., 1983. Computer-assisted quality control in tree-ring dating and measurement. Tree-Ring Bull. 43, 69-78.

Jones, P.D., Lister, D.H., Osborn, T.J., Harpham, C., Salmon, M., Morice, C.P., 2012. Hemispheric and large-scale land-surface air temperature variations: an extensive revision and an update to 2010. J. Geophys. Res.: Atmos. 117, D05127. http://dx.doi.org/10.1029/2011JD017139.

Kalra, A., Miller, W.P., Lamb, K.W., Ahmad, S., Piechota, T., 2013. Using large-scale climatic patterns for improving long lead time streamflow forecasts for Gunnison and San Juan River Basins. Hydrol. Process. 27, 1543-1559. http:// dx.doi.org/10.1002/hyp.9236.

Kaufman, D.S., Bright, J., Dean, W.E., Rosenbaum, J.G., Moser, K., Anderson, R.S., Colman, S.M., Heil Jr., C.W., Jiminez-Moreno, G., Reheis, M.C., Simmons, K.R. 2009. A quarter-million years of paeloenvironmental change at Bear Lake, Utah and Idaho. In: Rosenbaum, J.G., Kaufman, D.S. (Eds.), Paleoenvironments of Bear Lake, Utah and Idaho, and Its Catchment. The Geological Society of America, Special Paper 450 (Chapter 14).

Knight, T.A., Meko, D.M., Baisan, C.H., 2010. A bimillennial-length tree-ring reconstruction of precipitation for the Tavaputs Plateau, northeastern Utah. Quatern. Res. 73, 107-117.

Lamb, H.H., 1965. The early medieval warm epoch and its sequel. Palaeogeogr. Palaeoclimatol. Palaeoecol. 1, 13-37. http://dx.doi.org/10.1016/00310182(65)90004-0.

MacDonald, G.M., Tingstad, A.H., 2007. Recent and multicentennial precipitation variability and drought occurence in the Uinta Mountains region, Utah. Arct. Antarct. Alp. Res. 39, 549-555. http://dx.doi.org/10.1657/1523-0430(06070)[MACDONALD]2.0.CO;2.

Meko, D.M., Woodhouse, C.A., Baisan, C.H., Knight, T.A., Lukas, J.J., Hughes, M.K., Salzer, M.W., 2007. Medieval drought in the upper Colorado River Basin. Geophys. Res. Lett., 34.

Mock, C.J., 1996. Climatic controls and spatial variations of precipitation in the western United States. J. Clim. 9, 1111-1125. http://dx.doi.org/10.1175/15200442(1996)009<1111:CCASVO>2.0.CO;2.

Munroe, J.S., 2006. Investigating the spatial distribution of summit flats in the Uinta Mountains of northeastern Utah, USA. Geomorphology 75, 437-449.

R. Development Core Team, 2012. R: A Language and Environment for Statistical Computing. R Foundation for Statistical Computing, Vienna, Austria. ISBN 3900051-07-0.

Shaw, J.D., Long, J.N., 2007. Forest ecology and biogeography of the Uinta Mountains, USA. Arct. Antarct. Alp. Res. 39, 614-628.

Smith, T.M., Reynolds, R.W., Peterson, T.C., Lawrimore, J., 2008. Improvements to NOAA's historical merged land-ocean surface temperature analysis (18802006). J. Clim. 21, 2283-2296. http://dx.doi.org/10.1175/2007JCLI2100.1.

Speer, J.H., 2010. Fundamentals of Tree-ring Research. University of Arizona Press, Tucson, AZ, USA

Spond, M.D., van de Gevel, S.L., Grissino-Mayer, H.D., 2014. Climate-growth relationships for Rocky Mountain juniper (Juniperus scopulorum Sarg.) on the volcanic badlands of western New Mexico, USA. Dendrochronologia 32, 137143. http://dx.doi.org/10.1016/j.dendro.2014.03.001.

Stockton, C.W., Jacoby, G.C., 1976. Long-term surface-water supply and streamflow trends in the Upper Colorado River Basin based on tree-ring analyses. Lake Powell Res. Proj. Bull. 18, 1-70.

Stokes, M.A., Smiley, T.L., 1968. An Introduction to Tree-ring Dating. University of Chicago Press, Chicago, IL.

Strachan, S., Biondi, F., Leising, J., 2011. 550-Year reconstruction of streamflow variability in Spring Valley, Nevada. J. Water Resour. Plan. Manage. 138, 326333. http://dx.doi.org/10.1061/(ASCE)WR.1943-5452.0000180.

Wang, S.-Y., Gillies, R.R., Jin, J., Hipps, L.E., 2010. Coherence between the Great Salt Lake level and the Pacific quasi-decadal oscillation. J. Clim. 23, 2161-2177.

Wang, S.-Y., Gillies, R.R., Reichler, T., 2012. Multidecadal drought cycles in the Great Basin recorded by the Great Salt Lake: modulation from a transition-phase teleconnection. J. Clim. 25, 1711-1721.

Wang, S.-Y., Hakala, K., Gillies, R.R., Capehart, W.J., 2014. The Pacific quasi-decadal oscillation (QDO): an important precursor toward anticipating major flood events in the Missouri River Basin? Geophys. Res. Lett. 41. http://dx.doi.org/ 10.1002/2013GL059042.

Watson, T.A., Barnett, F.A., Gray, S.T., Tootle, G.A., 2009. Reconstructed streamflows for the headwaters of the Wind River, Wyoming, United States. J. Am. Water Resour. Assoc. 45, 1-13.

Welsh, L.W., Endter-Wada, J., Downard, R., Kettenring, K.M., 2013. Developing adaptive capacity to droughts: the rationality of locality. Ecol. Soc. 18. http:// dx.doi.org/10.5751/ES-05484-180207.

Wigley, T.M.L., Briffa, K.R., Jones, P.D., 1984. On the average value of correlated time series, with applications in dendroclimatology and hydrometeorology. J. Appl. Meteorol. 23, 201-213.

Wise, E.K., 2010. Tree ring record of streamflow and drought in the upper Snake River. Water Resour. Res. 46, w11529.

Woodhouse, C.A., Lukas, J.J., 2006. Drought, tree rings and water resource management in Colorado. Can. Water Resour. J. 31, 297-310. http:// dx.doi.org/10.4296/cwrj3104297.

Woodhouse, C.A., Gray, S.T., Meko, D.M., 2006. Updated streamflow reconstructions for the upper Colorado River basin. Water Resour. Res. 42, w05415.

Woodruff, D.R., Meinzer, F.C., McCulloh, K.A., 2010. Height-related trends in stomatal sensitivity to leaf-to-air vapour pressure deficit in a tall conifer. J. Exp. Bot. 61, 203-210. http://dx.doi.org/10.1093/jxb/erp291.

Xue, Y., Smith, T.M., Reynolds, R.W., 2003. Interdecadal changes of 30-Yr SST normals during 1871-2000. J. Clim. 16, 1601-1612. http://dx.doi.org/10.1175/ 1520-0442(2003)016<1601:ICOYSN>2.0.CO;2.

Yamaguchi, D.K., 1991. A simple method for cross-dating increment cores from living trees. Can. J. For. Res. 21, 414-416.

Zang, C., Biondi, F., 2013. Dendroclimatic calibration in R: the bootRes package for response and correlation function analysis. Dendrochronologia 31, 68-74. http://dx.doi.org/10.1016/j.dendro.2012.08.001. 